\title{
Peningkatan Prestasi Belajar Matematika Materi Menentukan Rata-Rata Hitung, Modus, dan Median Sekumpulan Data Melalui Model Pembelajaran Group Investigation (GI)
}

\author{
Eni Mardiyah \\ SD Negeri 1 Karangan Kecamatan Karangan Kabupaten Trenggalek, \\ Jawa Timur, Indonesia \\ Email: enimardiyah@gmail.com
}

\begin{abstract}
Abstrak: Penelitian ini menggunakan pembelajaran konstektual melalui model Group Investigation (GI) pada standar kompetensi Pengolahan Data dengan memilih kompetensi dasar menentukan rata-rata hitung, modus, dan median sekumpulan data pada siswa kelas VI di SD Negeri 1 Karangan Kec. Karangan, Kab. Trenggalek. Rancangan pembelajaran ini diharapkan dapat menciptakan suasana pembelajaran yang berpusat pada siswa sehingga terjadi pembelajaran yang aktif, kreatif, inovatif, efektif dan menyenangkan. Penelitiaan ini adalah penelitian tindakan (action research). Pembelajaran menentukan rata-rata hitung,

Tersedia Online di

http://journal.unublitar.ac.id/pendidikan/i ndex.php/Riset_Konseptual

Sejarah Artikel

Diterima pada: 27-01-2021

Disetuji pada: 30-01-2021

Dipublikasikan pada: 31-01-2021

\section{Kata Kunci:}

Prestasi Belajar, Pengolahan Data, Group

Investigation (GI).

DOI:

http://doi.org/10.28926/riset_konseptual.v5i1.320 modus, dan median sekumpulan data dengan model Group Investigation ini dilaksanakan dengan dua siklus. Hasil penelitian menunjukkan bahwa terdapat peningkatan hasil belajar setelah diterapkannya model GI. Hal ini dapat diketahui dari nilai pada siklus I yang awalnya belum tuntas. Siswa yang mencapai ketuntasan sebanyak 13 anak dengan prosentase $65 \%$. Sedangkan pada siklus II hasil pembelajaran peserta didik sudah mencapai ketuntasan, karena siswa yang telah tuntas sebanyak 17 anak dengan prosentase sebesar $85 \%$. Sehingga dapat disimpulkan terdapat peningkatan nilai rata-rata dari 69 pada siklus I menjadi 80 pada siklus II.
\end{abstract}

\section{PENDAHULUAN}

IImu matematika merupakan ilmu yang dibutuhkan dalam kehidupan seharihari. Matematika merupakan salah satu mata pelajaran wajib yang diajarkan di hampir di semua jenjang pendidikan mulai dari sekolah dasar sampai dengan sekolah menengah atas dengan alokasi waktu yang cukup banyak. Maka diperlukan pengelolaan kelas yang baik. Proses manajemen kelas yang baik akan menjadikan guru, siswa ataupun personil sekolah yang terkait lebih efektif dan efisien. Siswa tidak lagi hanya mendengarkan apa yang diajarkan guru, tetapi antara guru dan murid saling interaksi, saling memberikan input untuk mencapai tujuan pendidikan.

Realita yang terjadi selama tiga tahun terakhir setiap kali membahas pokok bahasan menentukan rata-rata hitung, modus, dan median sekumpulan data pembelajaran kurang berhasil. Ketidakberhasilan itu dikarenakan guru dalam penyajian pembelajaran masih menggunakan metode ceramah, penugasan, karena metode ini memang dianggap mudah dalam melaksanakan. Guru juga kurang memanfaatkan media pembelajaran sehingga proses pembelajaran lebih berpusat pada guru. Akibatnya siswa pasif, kurang tertarik terhadap materi pembelajaran, bekerja kalau ada tugas dari guru yang pada akhirnya mempengaruhi terhadap hasil belajarnya. Terbukti dari 20 siswa baru $55 \%$ atau 11 siswa yang nilainya $\geq 70$, dan $45 \%$ atau 9 siswa nilainya masih dibawah KKM atau kurang dari 70. Meskipun demikian seorang guru tidak boleh menyerah dengan kondisi yang dihadapi, dengan berusaha dan mencoba 
melakukan pembaharuan atau penyempurnaan dalam kegiatan pembelajaran sehingga hasil yang dicapai bisa lebih meningkat sesuai dengan yang diharapkan.

Berdasarkan permasalahan pembelajaran tentang Menentukan rata-rata hitung (mean), modus, dan median sekumpulan data, strategi pembelajaran kooperatif dengan Model pembelajaran Group Investigation (GI)akan peneliti terapkan untuk menciptakan situasi pembelajaran yang lebih aktif, kreatif, efektif, dan menyenangkan. Pembelajaran dengan metode ini lebih menekankan interaksi antara Guru dengan siswa maupun siswa dengan siswa. Dari sini siswa akan melakukan komunikasi aktif dengan sesama teman. Dengan komunikasi tersebut diharapkan siswa dapat menguasai materi pelajaran dengan mudah karena ada sebagian anak yang lebih mudah belajar dengan teman sebaya, dibanding penjelasan dari guru karena taraf pengetahuan serta pemikiran mereka lebih sejalan dan sepadan (Sulaiman dalam Wahyuni 2001:2).

Dalam pembelajaran mata pelajaran matematika materi menentukan rata-rata hitung, modus, dan median sekumpulan data sebelum menggunakan model pembelajaran Group Investigation (GI) menunjukkan hasil belajar siswa kelas VI SD Negeri 1 Karangan masih kurang, hal ini terbukti masih banyak siswa yang hasil belajarnya dibawah KKM, yaitu 70 . Berdasarkan hasil pra tindakan dapat diketahui bahwa nilai rata-rata kelas adalah 65 dan masih di bawah KKM yang ditetapkan, dimana terdapat 11 anak yang mendapat nilai 70 keatas, dan 9 siswa memperoleh nilai di bawah KKM. Jika dikonversikan dalam bentuk persen $55 \%$ siswa nilainya mencapai KKM dan 45\% siswa nilainya masih di bawah KKM.

Berdasarkan hasil belajar siswa yang diperoleh pada pra tindakan tersebut perlu diadakan perbaikan pembelajaran. Oleh karena itu, peneliti dalam melaksanakan penelitian ini akan menggunakan model pembelajaran Group Investigation (GI) sebagai alternatif pemecahan masalah yang dihadapi dalam pembelajaran selama ini dengan tujuan untuk meningkatkan prestasi belajar siswa khususnya pada pelajaran matematika materi menentukan rata-rata hitung, modus, dan median di SD Negeri 1 Karangan Kec. Karangan Kabupaten Trenggalek semester 2 tahun pelajaran 2016/2017.

\section{METODE}

Penelitian Tindakan Kelas ini dilakukan di SD Negeri 1 Karangan di mana tempat peneliti bertugas. Dikatakan Penelitian Tindakan Kelas karena permasalahan timbul di dalam kelas dengan ditandai rendahnya tingkat kemampuan siswa dalam menerima pembelajaran dan akan dipaparkan dalam bentuk siklus. Penelitian ini terdiri dari 2 Siklus, pada tiap siklus terdapat dua pertemuan. Tiap siklus dilaksanakan dalam empat tahap yaitu perencanaan, pelaksanaan, pengamatan dan refleksi. Subjek dalam penelitian ini adalah siswa kelas VI SD Negeri 1 Karanagan Kecamatan Karangan Kabupaten Trenggalek yang beralamatkan di Jl. P. Sudirman No. 43 dengan jumlah siswa 20. Hal ini peneliti tentukan karena di kelas VI SD Negeri 1 Karangan nilai ratarata siswa pada mata pelajaaran matematika materi menentukan rata-rata hitung, median, dan modus sekumpulan data masih di bawah KKM yaitu 70. Teknik Pengumpulan Data menggunakan teknik dokumentasi dan tes. Teknik Analisis Data menggunakan teknik analisis deskriptif kualitiatif.

\section{Siklus I}

\section{HASIL DAN PEMBAHASAN}

Perencanaan Penelitian Tindakan Kelas siklus 1 ini dilaksanakan di SDN 1 Karangan pada tanggal 7 dan 9 September 2017 dengan materi rata-rata. Pada tahap perencanaan ini, peneliti membuat Rencana Pelaksanaan Pembelajaran (RPP) dengan langkah yang mencerminkan kegiatan siswa sesuai dengan langkah-langkah model GI, LKS, soal tes, dan alat-alat pengajaran yang mendukung. Pelaksanaan kegiatan belajar mengajar untuk siklus I dilaksanakan pada hari Selasa, tanggal 7 dan 9 Maret 2017 di Kelas VI dengan jumlah siswa 20 . Dalam hal ini peneliti bertindak sebagai guru. Adapun langkah- langkah pada pelaksanaan ini adalah: 
Di kegiatan Inti ini guru membagi siswa menjadi 4 kelompok heterogen. Kemudian guru menjelaskan maksud pembelajaran dan langkah-langkah kegiatanya.Setelah terbentuk kelompok masing-masing kelompok memilih ketua kelompok, dilanjutkan guru membagi tugas kelompok materi rata-rata dengan soal yang tidak sama antar kelompok. Adapun tugas masing-masing kelompok seperti berikut: Kelompok I mendapat materi tentang menentukan rata-rata dari data yang disajikan dalam bentuk table, Kelompok 2 mendapat materi tentang menentukan rata-rata dari data yang disajikan dalam bentuk diagram batang, Kelompok 3 mendapat materi tentang masalah yang berhubugan dengan rata-rata jika diketahui rata-rata dan jumlah data, dan Kelompok 4 mendapat materi tentang masalah yang berhubungan dengan rata-rata jika diketahui rata-rata dan banyak data.

Setelah mendapat tugas masing-masing kelompok berdiskusi dengan teman sekelompoknya. Karena waktunya sudah habis maka guru meminta siswa mengakhiri diskusi dan soal di tinggal di sekolah untuk diteruskan pada hari Kamis dan meminta siswa kembali ke tempat duduk semula.

Di kegiatan inti pertemuan dua ini guru menyuruh siswa untuk membentuk diskusi seperti hari Selasa dan meneruskan diskusinya yang kemarin belum selesai, dan menuliskannya hasil diskusi dilembar diskusi.Setelah semua kelompok selesai berdiskusi secara bergantian wakil kelompok mempresentasikan hasil diskusinya ke depan kelas dan kelompok lain menanggapinya.Tidak lupatepuk tangan dari teman dan reaward dari guru pada siswa yang berani presentasi.

Pada Kegiatan Belajar Mengajar (KBM) siklus satu materi perkem bangbiakan tumbuhan ini sudah ada peningkatan dalam proses pembelajaran, dengan ditandainya prestas hasil evaluasi siklus satu meningkat dibandingkan dengan nilai pra siklus walaupun belum maksimal. Hasil evaluasi atau penilaian siklus 1 sebagai berikut:

Tabel 1. Hasil belajar Siswa Pada Siklus I

\begin{tabular}{|c|c|c|c|}
\hline No & Nilai & Frekuensi & Persentase \\
\hline 1 & 100 & - & - \\
\hline 2 & 90 & - & - \\
\hline 3 & 80 & 6 & 30 \\
\hline 4 & 70 & 7 & 35 \\
\hline 5 & 60 & 6 & 30 \\
\hline 6 & 50 & 1 & 5 \\
\hline \multicolumn{2}{|c|}{ Jumlah } & 20 & 100 \\
\hline
\end{tabular}

Dari hasil penilaian yang dilaksanakan setelah siklus 1 ada dua ketegori dalam penguasaan siswa, dapat dirinci seperti berikut:1) Siswa dengan tingkat penguasaan 80 sebanyak 6 anak (30\%), 2) Siswa dengan tingkat penguasaan 70 ada 7 anak (35\%), 3) Siswa dengan tingkat penguasaan 60 ada 6 anak (30\%), dan 4) Siswa dengan tingkat penguasaan 50 ada 1 anak(5\%). Dari paparan data penguasaan materi Rata- rata melalui model pembelajaran GI tampak memiliki tingkat penguasaan materi diatas KKM (70) ada 13 anak (65\%), dengan nilai rata-rata 69.

$\mathrm{Hal}$ ini menunjukkan penguasaan materi sudah meningkat dibandingkan sebelum diadakannya tindakan, namun secara klasikal penguasaan materi belum terpenuhi. Presentase ketuntasan hasil penilaian siklus 1 tertera pada tabel berikut ini:

Tabel 2. Ketuntasan belajar Siklus 1

\begin{tabular}{|c|c|c|c|c|c|}
\hline No & Nilai & Frekuensi & $\mathbf{N} \times \mathbf{F}$ & Persentase & Ket. \\
\hline 1 & 80 & 6 & 480 & 30 & Tuntas \\
\hline 2 & 70 & 7 & 490 & 35 & Tuntas \\
\hline 3 & 60 & 6 & 360 & 30 & Tidak Tuntas \\
\hline 4 & 50 & 1 & 50 & 5 & Tidak Tuntas \\
\hline \multirow{2}{*}{\multicolumn{3}{|c|}{$\frac{\text { Jumlah }}{\text { Rata-raa }}$}} & 1380 & 100 & \\
\hline & & & 69 & & \\
\hline
\end{tabular}

Berdasarkan tabel diatas diketahui bahwa siswa yang telah tuntas memperoleh nilai sama dengan atau lebih besar dari pada 70 dalam siklus 1 sebanyak 13 siswa (65). 
Presentase ketuntasan belum mencapai krikteria yang ditentukan sebesar $80 \%$. Ratarata nilai siklus 1 sebesar 69,00 .

Berdasarkan hasil pengamatan, peneliti melakukan refleksi terhadap aktifitas dan hasil belajar mata pelajaran matematika materi menentukan rata-rata hitung, sekumpulan data siswa kelas VI SD Negeri 1 Karangan Kecamatan Karangan Kabupaten Trenggalek. Pada kegiatan ini peneliti berfikir ulang terhadap apa yang sudah dilakukan, apa yang belum dilakukan, apa yang sudah dicapai, apa yang belum dicapai, masalah apa yang sudah terpecahkan, masalah apa yang belum terpecahkan. Kegiatan ini peneliti menelaah pelaksanaan pembelajaran dengan berdasarkan RPP dan catatan lapangan serta menilai hasil tes untuk mengetahui tingkat keberhasilan pembelajaran.

Guru selaku peneliti telah melaksanakan pembelajaran sesuai dengan rencana pelaksanaan pembelajaran (RPP). Guru senantiasa memfasilitasi pembelajaran siswa dengan berkeliling dari kelompok ke kelompok sambil menanyakan kesulitan yang dialami oleh masing- masing kelompok. Pada saat diskusi kelompok masih ada siswa yang pasif malah bercanda dengan teman dekatnya sehingga saat kurang menguasai materi yang sedang dipelajari.ia hanya duduk menunggu temannya yang lagi mengerjakan lembar diskusi kelompok. Prestasi belajar siswa pada siklus 1 ini kurang karena belum mencapai ketuntasan minimal secara klasikal. Siswa yang tuntas belajar sebanyak 13 anak (65\%). Ketuntasan belum mencapai minimal $80 \%$. Rata- rata nilai 69,00 dan belum mencapai KKM.

Penyebab utama kekurangan berhasilnya tersebut adalah penggunaan model pembelajaran GI masih baru, dan siswa kurang aktif kadang dia masih mengandalkan temannya yang dianggap bisa. Oleh karena itu pelaksanaan pembelajaran perlu ditingkatkan dan model pembelajaran jigsaw perlu di variasi sehingga nantinya akan terwujud pembelajaran yang aktif, kreatif, evektif dan menyenagkan. Dengan demikian penelitian ini perlu dilanjutkan ke siklus 2 sehingga prestasi siswa bisa meningkat maksimal.

\section{Siklus II}

Perencanaan Penelitian Tindakan Kelas Siklus II dilaksanakan selama dua pertemuan di SDN 1 Karangan.Pertemuan kesatu dilaksanakan pada tanggal 21 Maret dan pertemuan kedua pada tanngal 24 Maret 2017. Kegiatan pada tahap ini meliputi: mempersiapkan rencana pelaksanaan pembelajaran (RPP) dengan materi Median dan Modus. Berdasarkan pengamatan saat diskusi pada siklus 1 belum maksimal karena masih ada anak yang diam hanya menulis jawaban dari teman, untuk itu diharapkan pada siklus II saat diskusi semuanya lebih aktif.

Untuk meningkatkan motivasi belajar siswa, pada siklus II ini siswa diminta untuk mencatat hasil diskusi kelompok di buku masing - masing serta pada waktu mempresentasikan hasil kerja kelompok guru memilih secara acak. Hal ini dilakukan guru agar semua anak aktif tidak ada yang hanya diam dan mengandalkan teman yang bisa.Selain itu diberikan penghargaan kepada kelompok yang berprestasi, yaitu aktif dalam kegiatan pembelajaran dan dalam mempresentasikan hasil diskusi diambil terbaik 1,2 dan 3 diumumkan. Siklus II dilaksanakan dalam dua pertemuan yaitu pada tanggal 21 dan 24 Maret 2017 dengan materi Median dan Modus. Pada pertemuan pertama guru menjelaskan bahwa dalam mempelajari materi Median dan Modus ini langkah-langkah kegiatan pembelajaran masih sama dengan pertemuan sebelumnya yaitu dengan membagi siswa kelas VI menjadi 4 kelompok heterogen. Kemudian guru menjelaskan dan mengingatkan maksud pembelajaran dan langkah-langkah kegiatanya. Setelah terbentuk kelompok masing-masing kelompok memilih ketua kelompok, dilanjutkan guru membagi tugas kelompok materi Median dan Modus dengan soal yang tidak sama antar kelompok. Adapun tugas masing-masing kelompok seperti berikut: Kelompok I mendapat materi tentang menentukan median dari data ganjil., Kelompok 2 mendapat materi tentang menentukan median dari data genap, Kelompok 3 mendapat materi tentang median dari data yang disajikan dalam bentuk table, dan Kelompok 4 mendapat materi tentang modus dari sekumpulan data.Setelah mendapat tugas masing-masing 
kelompok berdiskusi dengan teman sekelompoknya. Karena waktunya sudah habis maka guru meminta siswa mengakhiri diskusi dan soal di tinggal di sekolah untuk diteruskan pada hari Kamis dan meminta siswa kembali ke tempat duduk semula.

Pada pertemuan kedua guru menyuruh siswa untuk kembali pada kelompok diskusi seperti pada hari Selasa dan meneruskan diskusinya yang kemarin belum selesai. Setelah diskusi menyelesaikan tugasnya secara kelompok dilanjutkan masingmasing anggota kelompok menulis hasil kerja kelompoknya di buku masing-masing .Setelah semua anggota kelompok selesai menuliskan hasil diskusi dibuku tulis masingmasing, maka guru mengacak siswa untuk mempresentasikan hasil diskusi kelompok di depan kelas, yang nantinya akan ditanggapi oleh kelompok lain.saat wakil kelompok mempresentasikan hasil tugas kelompok siswa diminta untuk menilai presentasi tadi yang nantinya akan diambil juara 1,2, dan 3 sebagai motivasi dan tepuk tangan serta reawead dari teman serta gurunya untuk temannya yang berani mempresentasikan hasil kerja kelompoknya, kemudian guru memberi kesempatan kepada siswa untuk bertanya.

Pengamatan terhadap pelaksanaan kegiatan pembelajaran dilakukan oleh peneliti sendiri bersaman dengan pelaksanaan proses pembelajaran. Pada kegiatan penutup guru memberikan evaluasi secara tertulis untuk mengetahui tingkat pemahaman siswa terhadap materi pembelajaran hari ini.

Tabel 3. Hasil Penilaian Tes Tulis Pada Siklus II

\begin{tabular}{|c|c|c|c|}
\hline No & Nilai & Frekuensi & Persentase \\
\hline 1 & 100 & 2 & 10 \\
\hline 2 & 90 & 5 & 25 \\
\hline 3 & 80 & 7 & 35 \\
\hline 4 & 70 & 3 & 15 \\
\hline 5 & 60 & 3 & 15 \\
\hline \multicolumn{2}{|c|}{ Jumlah } & 20 & 100 \\
\hline
\end{tabular}

Dari hasil penilaian yang dilakukan setelah siklus II ada tiga kategori yaitu: 1) Siswa dengan tingkat penguasaan 100 sebanyak 2 siswa $(10,00)$, 2) Siswa dengan tingkat penguasaan 90 sebanyak 5 siswa $(25,00)$, 3) Siswa dengan tingkat penguasaan 80 sebanyak 7 siswa $(35,00)$, 4) Siswa dengan tingkat penguasaan 60 sebanyak 3 $(15,00)$, dan 5) Siswa dengan tingkat penguasaan 60 sebanyak 3 siswa $(15,00)$ Dari data penguasaan materi Median dan Modus tampak memiliki tingkat penguasaan materi sama atau diatas KKM (70) sebanyak 17 anak (85\%). Hal ini menunjukkan bahwa penguasaan materi pada siklus II telah mencapai indikator.

Adapun presentase ketuntasan hasil penilaian pada siklus II dapat dipaparkan pada tabel berikut ini:

Tabel 4. Ketuntasan Penilaian Siklus II

\begin{tabular}{|c|c|c|c|c|c|}
\hline No & Nilai & Frekuensi & N x F & Persentase & Ket. \\
\hline 1 & 100 & 2 & 200 & 10 & Tuntas \\
\hline 2 & 90 & 5 & 450 & 25 & Tuntas \\
\hline 3 & 80 & 7 & 560 & 35 & Tuntas \\
\hline 4 & 70 & 3 & 210 & 15 & Tuntas \\
\hline 5 & 60 & 3 & 180 & 15 & Tidak Tuntas \\
\hline \multicolumn{2}{|c|}{ Jumlah } & 20 & 1600 & 100 & \\
\hline \multicolumn{2}{|c|}{ Rata-rata } & 80 & & \\
\hline
\end{tabular}

Berdasarkan tabel diatas diketahui bahwa siswa yang telah tuntas memperoleh nilai sama atau diatas KKM (70) dalam siklus II sebanyak 17 siswa (85\%). Presentase ketuntasan telah mencapai krekteria yang telah ditentukan sebesar $80 \%$. Nilai rata- rata pada siklus II sebesar 80 dan telah mencapai KKM (70).

Pada tahap ini akan dikaji apa yang telah terlaksana dengan baik maupun yang masih kurang baik dalam proses belajar mengajar dengan penerapan Pembelajaran kooperatif model Group Investigation (Gl). Dari data-data yang telah diperoleh dapat diuraikan sebagai berikut: a) Guru telah melaksanakan proses pembelajaran mata pelajaran matematika dengan model Gl dengan baik. Hal ini berarti bahwa guru telah 
melaksanakan fungsinya sebagai fasilitator dengan baik. b) Siswa telah mengikuti model pembelajaran GI sesuai dengan scenario pembelajaran. Hal ini berarti bahwa siswa dapat menerima perubahan pembelajaran. c) Penerapan model pembelajaran GI menjadikan siswa lebih aktif dan kreatif sehingga siswa tampak lebih bersemangat dalam pembelajaran dan suasana kelas lebih menyenangkan. d) Hasil belajar siswa pada siklus II mencapai ketuntasan.

Pada siklus II guru telah menerapkan Pembelajaran kooperatif model Group Investigation (GI) dengan baik dan dilihat dari aktivitas siswa serta hasil belajar siswa dalam pelaksanaan proses belajar mengajar sudah berjalan dengan baik. Maka tidak diperlukan revisi terlalu banyak, tetapi yang perlu diperhatikan untuk tindakan selanjutnya adalah memaksimalkan dan mepertahankan apa yang telah ada dengan tujuan agar pada pelaksanaan proses belajar mengajar selanjutnya penerapan Pembelajaran kooperatif model Gl dapat meningkatkan sehingga tujuan pembelajaran dapat tercapai secara optimal.

Keberhasilan pembelajaran materi "Menentukan rata-rata hitung (mean), modus dan median dengan menggunakan model pembelajaran GI sudah baik. Hal ini dapat dilihat dari keberhasilan siswa pada peningkatan hasil evaluasi yang dapat diketahui dengan cara membandingkan hasil nilai evaluasi siswa pada Pra Siklus dengan nilai rata-rata 65 dengan tingkat ketuntasan 55\%, Siklus I dengan nilai rata-rata 69,00 dengan tingkat ketuntasan $65 \%$ dan Siklus II dengan nilai rata-rata 80 dengan tingkat ketuntasan $85 \%$. Untuk lebih jelasnya dapat dilihat pada diagram berikut:

Grafik 1. Perkembangan Prestasi Belajar Siswa

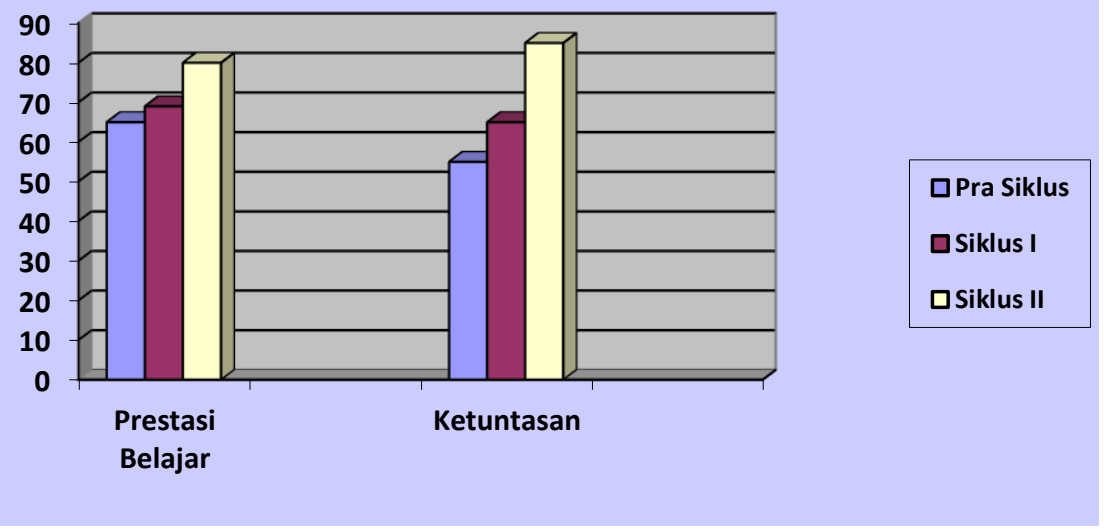

Berdasarkan diagram di atas terdapat peningkatan prestasi siswa dalam hal mata pelajaran matematika materi menentukan rata-rata hitung, modus, dan median sekumpulan data pada siswa kelas VI semester 2 tahun pelajaran 2016/2017 SD Negeri 1 Karangan sebagai berikut. Pra siklus rerata 65 dengan ketuntasan 55\%, Siklus 1 rerata 69 dengan ketuntasan $65 \%$, Siklus II rerata 80 dengan ketuntasan $85 \%$. Dari pra siklus ke siklus I sebetulnya sudah ada peningkatan rerata yaitu 4 , dan peningkatan ketuntasan $10 \%$, namun belum mencapai ketuntasan kelas. Dari siklus I ke siklus II ada peningkatan rerata kelas 11, peningkatan ketuntasan $20 \%$. Secara klasikal ketuntasan kelas di siklus II sudah mencapai $85 \%$, berarti sudah memenuhu ketuntasan kelas yang ditetapkan yaitu $80 \%$.

Berdasarkan analisis data, diperoleh aktivitas siswa dalam proses Pembelajaran kooperatif model Group Investigation (Gl) mengalami peningkatan. Hal ini berdampak positif terhadap prestasi belajar siswa yaitu dapat ditunjukkan dengan meningkatnya nilai rata-rata siswa pada setiap siklus. Hal ini sejalan dengan Amiruddin (2015), Nupiksani (2015), dan Purnama (2013)

Berdasarkan analisis data, diperoleh aktivitas siswa dalam proses Pembelajaran kooperatif model Group Investigation (GI) adalah dominan, siswa berani untuk lebih aktif memberi /menyampaikan materi kepada sesama teman, sehingga suasana dalam proses pembelajaran lebih aktif, efektif, dan menyenangkan. Sedangkan untuk aktivitas 
guru selama pengajaran telah melaksanakan langkah-langkah Pembelajaran kooperatif model Group Investigation (Gl) dengan baik. Hal ini terlihat dari aktivitas guru yang muncul di antaranya aktivitas membimbing dan mengamati siswa dalam mengerjakan kegiatan LKS/menemukan konsep, menjelaskan/melatih berani berpendapat, memberi umpan balik/evaluasi/tanya jawab dimana prosentase untuk aktivitas di atas cukup besar.

\section{KESIMPULAN}

Dari hasil analisis data dapat diketahui bahwa hasil tes yang diperoleh pada siklus I memperoleh jumlah nilai 1380 dengan rata-rata 69. Sedangkan hasil tes siklus II memperoleh jumlah nilai 1600 dengan rata-rata 80 . Hasil siklus I maupun hasil siklus II dapat dibandingkan, bahwa hasil siklus II lebih baik dari hasil siklus I. Sehingga dapat dikatakan bahwa hasil siklus II mengalami peningkatan dibanding hasil siklus I. Peningkatan hasil belajar siswa tersebut dapat diketahui melalui instrument tes siklus I dengan rerata sebesar 69 siklus II rerata sebesar 80 sehingga terjadi peningkatan sebesar 11 dan hasil belajar yang diperoleh pada rentang nilai $50-100$, ketuntasan yang dicapai pada siklus I sebesar $65 \%$ siklus II sebesar $85 \%$ sehingga terjadi peningkatan sebesar $20 \%$. Dari analisis data diatas dapat disimpulkan bahwa melalui model pembelajaran Group Investigation (Gl), Prestasi belajar Matematika Materi Menentukan Rata-rata Hitung, Modus, dan Median Sekumpulan Data siswa kelas VI Semester 2 Tahun Pelajaran 2016/2017 SD Negeri 1 Karangan mengalami peningkatan.

\section{DAFTAR RUJUKAN}

Amiruddin. (2015). Peningkatan Prestasi Belajar IPS melalui metode Pembelajaran Group Investigation pada Siswa Kelas IV SDN 1 Tinauka. Jurnal Kreatif Tadulako. Vol. 3 No. 4

Purnama, Galih (2013) Upaya Peningkatan Prestasi Belajar dengan Metode Pembelajaran Kooperatif Investigasi Kelompok (Group Investigation) Mata Pelajaran Seni Budaya (Seni Musik) Pada Siswa Kelas IX A SMP NEGERI 3 Ambarawa. S1 Thesis, Universitas Negeri Yogyakarta

Nupiksani, Sri. (2015). Meningkatkan Hasil Belajar IPS Melalui Penerapan Model Pembelajaran Group Investigation Pada Siswa Kelas VI SDN Rejoagung 01 Kecamatan Semboro Kabupaten Jember. FKIP UNEJ. Vol 4 No 4

Wahyuni, Dwi. (2001). Studi Tentang Pembelajaran Kooperatif Terhadap Hasil Belajar Matematika. Malang: Program Sarjana Universitas Negeri Malang. 